\title{
The Two Versions of the Gramatyka Slovenskaja of Ivan Uževič
}

BY

\section{J. DINGLEY}

The Institute of Linguistics of the Ukrainian Academy of Sciences has recently published a facsimile reproduction of both the Paris (1643) and Arras (1645) versions of Uževič's Gramatyka Slovenskaja, edited by I. K. Bilodid and E. M. Kudryc'kyj. ${ }^{1}$ The editors have provided a lengthy introduction which includes both a survey of earlier references to Uževič and his grammar, a linguistic analysis, a translation of the Paris version into Ukrainian, notes to both grammars and a word-list.

In their linguistic analysis of the texts the editors have assumed that Uževič was a Ukrainian and that the language he was describing was Ukrainian. Earlier studies or references to the grammars have described Uževič's language variously as 'un mélange de slavon et

1. Hramatyka slovjans'ka I. Uževiča, Kiev, 1970.

Abbreviations used in the article are:

A. - the version of the grammar now kept in the Arras municipal library. The title page bears the date 1645 .

P. - the version of the grammar now kept in the Bibliothèque Nationale in Paris. The title page bears the place and date Parisiis 1643.

B-K the editors of the Kiev edition of Uževič's grammar, I. K. Bilodid and E. M. Kudryc'kyj.

$r$ recto.

$v$ verso.

The two versions differ in many respects. No attempt has been made in this article to enumerate all the differences. The Latin verse at the end of $P$. and the dedication of A. suggest that the manuscripts were prepared for individual benefactors; it is quite likely that Uževič intended to have his grammar published. A. in particular shows signs of having been carefully prepared for a printer, since for the most part the Slavonic letters are much more carefully written and there is less use of running hand (skoropis') and superscript letters.

Virtually the only direct clue given by Uževič to the nature of the language he describes is that it is spoken by the 'Rutheni'. 
polonais' $^{2}$ and 'kirchenslavisch-klein- oder weißrussische Sprache'. ${ }^{3}$ A reference not mentioned by the editors of the facsimile edition is contained in the Soviet Byelorussian journal Polymia, 2, Minsk, 1928, p. 232; it mentions the existence of a manuscript grammar of the Old Byelorussian literary language in the Bibliothèque Nationale in Paris. This information was repeated in the Byelorussian émigré journal Vieda, 1 (28), New York, 1954. The claim made by B-K, that Uževič's language is in fact Ukrainian, is the first to be backed by an analysis of the texts in question.

A reviewer of B-K's edition has said that it is somewhat premature to reach such a categorical conclusion ${ }^{4}$ without a more thorough-going examination of the two versions of the grammar and without knowing more about Uževič's origins. This is obviously important in taking into consideration the dialect base of his language. Unfortunately there is as yet little that can be said for certain about his life. It is known that on October 26th 1637, one Joannes Petri Uzewicz of the diocese of Vilna was enrolled as a student of the University of Cracow. ${ }^{5}$ In 1641 Uževič wrote and published a poem to celebrate the marriage of Alexander Przyłęcki and Ewa Rupniowska. On the other side of the sheet the arms of the Przyłęcki family was printed together with an eight-line poem in its honour. The author of the grammar describes himself on the title page of P. as 'Celeberrimae Academiae Parisiensis Studiosus Theologus'. No direct link has yet been established between the Uzewicz of Cracow and the Uževič of Paris, but there are reasonable grounds for assuming that they were one and the same person. It is obvious from the grammar that Uževič had an excellent command of Latin, as well as some knowledge of Greek and Hebrew. He was familiar with Old Church Slavonic, 'Bohemian' and 'Moravian' and Polish, including the principles of Polish versification (see the section entitled 'Carminum compositio', A83v). There is evidence to show that he was aware of current

2. J. Martinof SJ, Les manuscrits slaves de la Bibliothèque impériale de Paris, Paris, 1858, p. 36.

3. V. Jagić, 'Johannes Uževič, ein Grammatiker des XVII. Jahrh.', Archiv für Slavische Philologie, Bd. 29, H. 1, Berlin, 1907, p. 154. At the end of his article Jagić refers to the grammar as a 'Grammatik der kirchenslavischen Sprache'. The main difference between Uževič on 'the one hand, and Zizanij and Smotryckyj on the other, is that Uževič was not attempting to compile a normalizing grammar of Old Church Slavonic. On several occasions he shows that the corresponding forms in Old Church Slavonic are different. The archaizing influence of OCS can be felt in the dual forms of the verb given in P., and not surprisingly, the prayers which introduce both versions as samples of continuous writing are in the language of the Orthodox Church. In the main, however, Uževič describes a spoken East Slavonic language.

4. Review by M. B. in Viesnik Biełaruskaha dziaržaūnaha universiteta, 2 , Minsk, 1971, pp. 91-2.

5. Album Studiosorum universitatis Cracoviensis, 4, Cracow, 1950, pp. 179-80. On the title page of P., the author transliterates his name as Usevicius, on P70r as Ugevicius. Confusion of $z$ and $\check{z}$ is found in some of the Russian dialects of the Pskov area and in some northern Byelorussian dialects, see E. F. Karskij, Belorusy, I, Moscow, 1955, p. 358. The present author has found no examples of the confusion of these two sounds elsewhere in the grammar. 
linguistic theories. ${ }^{6}$ Moreover the Arras manuscript opens with a poem entitled 'на гербъ пано[в] Брыгалльровъ' written underneath the Brygallier (?) coat of arms.

One potentially important detail is treated rather too cursorily by $\mathrm{B}-\mathrm{K}$, viz. that Uževič came from the Vilna diocese. Clearly this can have two meanings. It can mean either, and this is how B-K understand it, that Uževič had received his education somewhere within the Vilna diocese, or that he did in fact originate there. In either case it would be helpful to give the precise delineation of the Vilna diocese, since Uževič would undoubtedly have been influenced by the language spoken there even if he had been born elsewhere. The deaneries of the diocese of Luck stretched as far north as Šerešovo, with the southern boundary of the diocese of Vilna running to the north of Bielsk-Podlaski, Pružany, Pinsk and Stolin, and then to the south of Pietrykaū, Mazyr and Rečyca. ${ }^{7}$ This means that practically all of present-day Byelorussia was contained in the diocese of Vilna.

An examination of certain features of Uževič's language, and in particular of B-K's criteria for regarding that language as Ukrainian, will provide much useful information which may help to locate the author's place of origin.

Of special interest for a study of the orthography and probable pronunciation are the alphabet tables (P5r, A6r), particularly that of A., where the sounds (as opposed to the Slavonic names of the letters) are given in Latin transcription. Noteworthy features are:

i) B, transliterated as 'uu' in A. Ižica is described as an occasionally used equivalent (P7r). In the past tense of verbs (P44r) both Poles and Ruthenians have писалемъ; some Ruthenians also say писавъемъ or писавемъ. The letter в therefore represents a bilabial continuant as in modern Byelorussian ( $\breve{y})$ and Ukrainian (B).

ii) $\Gamma$. In P. the name of this letter is transliterated as 'hlahol', in A. as 'głaoul' (with sound value 'h'). It cannot be deduced from

6. The use of the term 'verbum substantivum' to describe the verb 'to be' on P23r and A54v suggests that Uževič was familiar with F. Sanctius' Minerva seu de causis linguae latinae, Salamanca, 1587. This work enjoyed a great reputation internationally; the seventh edition, for example, "was published in Amsterdam in 1761.

7. D. Tolstoy, Le Catholicisme Romain en Russie, I, Paris, 1863, pp. 238-9 (diocese of Vilna), pp. 291-2 (diocese of Luck).

P. Rabinauskas (ed.), Relationes status diocesium in Magno Ducatu Lithuaniae, I, Rome, 1971, folding map at end of book.

The question of Uževič's religious affiliation is of obvious importance. Prayers on P3v, hymns on P71r, the Lord's Prayer in Old Church Slavonic $(\mathrm{A} 12 v)$ and in glagolitic script (A14v), and the Orthodox confession of faith on A $15 v$; make it reasonable to assume that he had at least been brought up as a member of the Orthodox Church and was familiar with its liturgy. On the other hand, it is difficult to conceive of an Orthodox, especially in the Grand Duchy of Lithuania in the seventeenth century, writing, even as a grammatical example, поехаль до римоу по благословенство (P69v). It seems possible, in view of this and of the fact that Uževič studied at Cracow and the Sorbonne, that he had at some stage become a Roman Catholic of either the eastern or western rite. 
this alone whether Uževič pronounced this consonant as a voiced velar fricative or voiceless glottal fricative $(h)$. The voiced velar plosive (g) constituted a distinct phoneme and was represented in writing by the digraph кг, e.g. кгды (P53r), жекгловалихмы (Р63r), Анкглї а (Р63v). The letter I also occurs once, in the word теологї и on the title page of $\mathrm{P}$.

iii) The sound of $\%$ is rendered as ' $\mathrm{g}$ ' in both $\mathrm{A}$. and P. The Slavonic name живьте is given as 'giuite'.

iv) The sound value of иже (i) is 'i'; that of и is ' $y$ ' (A6r). The name и is transliterated ' $i$ ' in both A. and P.

v) мысльте is transliterated 'myslite'.

vi) $p$ is named ирцђ (OCS рьци/рьцђ) and transliterated 'irci' in P., 'ircij' in A. This is the only example in both versions of prothetic 'i' before an originally initial liquid,

vii) The sound value of ц is given by the equivalent letter in the Hebrew alphabet in A. only,

viii) ы ('iory') has the sound value ' $y$ ' (in fine),

ix) $\mathrm{b}$ is named as 'iat' ' in P. and A.; its sound value in A. is 'ie'.

$\mathrm{x})$ In both P. and A. $\mathrm{b}$ is followed by 'e, named as 'ie' with the sound value of ' $\mathrm{e}$ '.

xi) the ia ligature and jus malyj have identical names and sound value ('ia'). They are represented elsewhere in this article by я.

xii) omega (placed between the two vowels mentioned above) appears as 'o in P.

xiii) $\pi$ (called юсъ) is given in A. only. Its sound value is ' $u$ '.

xiv) In both alphabet lists the final 'letter' is in fact a superscript mark, the '(slovo) titla', denoting abbreviations.

The order of the alphabet is much the same, but with differences in the placing of $\mathrm{x}$ and the accented vowels "o, 'e, as the order given in the published grammars and alphabet books of Old Church Slavonic with which Uževič was probably familiar. ${ }^{8}$ The commentary on the use of the letters is much fuller in P. than in A. Rules are given for the positioning of the vowel signs. Eight of them- 'a, 'e, $\ddot{i}$ и, ю, omega, plus uk (elsewhere represented in this article by the digraph oy) and the ia ligature - may be in initial, medial or final position; the other eight - $\mathrm{y}, \mathrm{b}, \mathrm{b}, \mathrm{b}, \mathrm{b}$ o, plus jus malyj and ižica cannot be initial. There are five diphthongs: the $i a$ ligature $=$ ia, ю $=$ io, $u k=$ ou, omega $=$ oo,

The use of accents is described only in $\mathrm{P}(\mathrm{P} 6 r)$. The acute accent on и denotes a lengthening in pronunciation. Other vowels also occur with this accent, e.g. о and я. Uževič is possibly referring to stress when he says that ì 'solet in dictionibus produci'. By no means all the words in the grammar bear this accent; even when it is used, it is not always consistent. With the grave accent $и$ and the other

8. L. Zizanij, Hrammatika slovenska, Vilna, 1596.

Hrammatika albo složenie pismena .... Vilna, 1618.

M. Smotryc'kyj, Hrammatiki slavenskija pravilnoe sintagma, Ev'e? 1618?

Bukvar' jazyka slavenska, Vilna, 1640.

Uževič was probably familiar with the other published Slavonic grammars of his day.

9. Zizanij did not include omega in his list of diphthongs. 
vowels form a syllable with the preceding consonant. If ì is preceded by a vowel, it is to be read as a separate syllable. If и bears the obliqua apostrophus (Й), then it forms part of the same syllable as the preceding vowel, e.g. nom. sing, небесный, nom. plu. небесный. Uževič was one of the first grammarians to describe the function of $\breve{\mathrm{n}}$, although at this stage it was not regarded as a separate letter. ${ }^{10}$ If и bears an apostrophus recta (и'), it is to be read separately from the following word. This also applies to o and я. The paeryk (represented in this article by an apostrophe) is frequently used to replace both й and ъ, е.g. которы' (Р19v), неха' (Р23v), в'железе (А33v), although its use is not explained. A variant sign, taking the form of a small letter ' $v$ ' is also found occasionally on the first consonant of a cluster, and on the preposition в (P8r, P22r). Elsewhere consonant groups are unmarked or have $\mathrm{b}$ interspersed: ангели, арханъгели (both P4r), пекелны' (ь missing, P9v), писавъшы (Р61r), написавши (A81r). The preposition в is occasionally joined to the following word without paeryk or a dividing hard sign: втыхь дняхь (Р62v); the other single-letter preposition (3) is always used with paeryk. It is given as a spelling rule that no consonant may stand alone in final position, unless written above the line. The nearest Uževič approaches to a description of palatal consonants is to say that $\mathbf{b}$ is pronounced 'asperius' and b 'mollius ... cum sua consonante'.

B-K take a number of phonetic features from the texts which are common to both Byelorussian and Ukrainian. These are:

i) Hardening of historically soft final labials: кровъ, бровъ, (P13v).

ii) the hard r, cf. говороу (P40v), вароу (A47r), Хрыстоу (P5r). The spelling варять is also found (A47v), as against варачи $(\mathrm{A} 49 v)$.

iii) $\mathrm{b}>e$. It is surprising that this is regarded as a common feature, the more so since later the change $\mathrm{b}>i$ is used in citing examples to prove that Uževič's language is Ukrainian. This latter change is normally regarded as one of the most distinctive features of standard Ukrainian, 'das nur den einförmig ikavischen Reflex fur Jat kennt'. ${ }^{11}$ Many spellings in both versions of the grammar betray the identical pronunciation of $b$ and $e$ : льсь, лесы (both $\mathrm{P} 13 r$ ), в желези (P17v, A33v), в жельзи (P69v, А33v), спеваю (Р31r), спњваю (Р34r), грешоу (Р36v), грђшныхъ (Р65v), бегоу (P37r, P44v - for бъгу, cf. Ukrainian бігати), едь (Р27v, for ьдь), вдоу (Р37v - historically correct, but by Uževič's own spelling rule, $\mathrm{b}$ ought not to be in initial position), ръжоу (Р39v, for режоу), мнъ/мне (both A34r).

Identical treatment of stressed Common Slavonic *ě is to be found in the virtually indistinguishable dialects of south-west Byelorussia and the northern Ukraine, ${ }^{12}$ where it passes to a polyphthong (ie). Of the examples listed above, two pairs have $\mathrm{b}$ in the stressed syllable

10. A. M. Bułyka, Raźvićcio arfahrafičnaj sistemy starabiełaruskaj movy, Minsk, 1970, p. 54.

11. R. Nahtigal, Die slavischen Sprachen, Wiesbaden, 1961, p. 148.

12. M. Samoilov, The phoneme Jat' in Slavic, The Hague, 1964, pp. 24-9. 
and e in the pretonic syllable: льсь лесы; грешо́у, гръшныхъ, cf. modern Byelorussian грашы' цъь, грэ'шны. There are however too many examples where $\mathrm{b}$ and $\mathrm{e}$ appear to be directly interchangeable to allow it to be assumed that Uževič was trying to represent two different allophones of $e$.

It is certainly true that none of the typically Byelorussian phonetic features - akańnie, dziekańnie, ciekańnie - are reflected in either text, but these features were very rarely incorporated into texts of the sixteenth and seventeenth centuries. ${ }^{3}$ Particularly in the seventeenth century this can be explained by the influence on spelling of the Church Slavonic grammars of Zizanij and Smotrickij. The absence of these features cannot be taken as evidence for Uževič's language not being Byelorussian.

B-K list a number of phonetic features which they regard as purely Ukrainian. The first of these is the change $b>i$. Following Karskij, ${ }^{14}$ examples of this change should be divided into separate phonetic and morphological categories. The following may be regarded as purely phonetic examples: греховъ (A16v), гриховъ (A19v), виншоую (Р32v, P57v), въьншоую (A78v), cf. Polish winszować and German wünschen. ${ }^{15}$ Many morphological examples involve the singular locative ending: на объды (P17v), but cf. в пане (P52v), в шашгв $(\mathrm{P} 60 v))$, на земли (Р67v), в мъсти (Р69г), на оуліци (А79r). The ending e is found with пань, староста; $b$ with небо, шапка; и with объдъ, злотогловъ, Іерданъ, место, железо, земля, челядь. One example of the locative plural ending ехъ $(<\mathrm{bxъ})$ is given with люди; the locative plural of веь is всьхь (А16r) or всихь (Р53r). Examples of the dative singular of original a-stem declension nouns can be found with either е or и: старосте (Р10v, А20r), монарше vel монарсе, матце, слузи, книзи, черзи (all A21v;). Plural imperative forms: поклонї мся (bis), поклонЊмъся (A14r), варь'мо, варђ'те (A48v).

In the phonetic examples both е and и occur as reflexes of $b$ in the pretonic syllable. A possible explanation is that spellings such as гриховъ are attempts to render in writing the pronunciation of unstressed $e$, whether derived from $\mathrm{b}$ or not. Such a pronunciation of both original and derived $\mathrm{e}$ is found in the dialects of the Brest and Pinsk regions. ${ }^{16}$ It may be that something similar is behind the use of и in the morphological examples listed above. None of the nouns which have и as the ending of the locative singular has the stress on that ending, except земля, which always had $i$ in that case (following the paradigm of original $j a$-stem nouns). Moreover, the ending и/ы is not alien to noun paradigms of modern literary Byelorussian: it occurs with nouns of all three genders with hardened or soft stems. In Byelorussian dialects it occurs even more widely, e.g.

13. Bułyka, op. cit., pp. 70, 76.

14. Karskij, op. cit., p. 214.

15. Виншовати is listed as an example of a Polish loan word in Histaryčnaja leksikatohija biełaruskaj movy, Minsk, 1970 (cited hereafter as HL), p. 116.

16. N. T. Vajtovič, Nienaciskny vakalizm narodnych havorak Biełarusi, Minsk, 1968, pp. 95 (map), 192. 
in the Pružany district, where it is found, unstressed, with hard-stem nouns. ${ }^{17}$ Elsewhere in south-western Byelorussia the endings $e$ and $i$ exist side by side. ${ }^{18}$ Uževič makes his own position quite clear on A33v: 'et hi Vagabundi Casus plerumque singulariter per и vel е efferuntur ut в желези vel в железе'. For him both endings were acceptable, and although it is not stated explicitly, the same probably applies to the dative singular ending of $a$-stem nouns.

It is hard to justify всихь as an example of purely Ukrainian spelling, since the modern Byelorussian word is ycix. Admittedly on the same page there occurs the form всъми, where Uževič may well have pronounced the $\mathrm{b}$ as $i$. The traditional spelling of these words must have exerted a powerful influence. In addition, it must be considered whether the plural declension of весь exhibits the phonetic change $\mathrm{b}>i$, or the morphological attraction of the plural declension of the demonstrative pronouns.

It cannot automatically be assumed that $\mathrm{b}$ (under stress) in the plural imperative forms варьмо, варь'те was read as $i$. The corresponding indicative forms are ва́римъ (А47r), варите (А47v), with change of stress position and different endings. The imperative endings -em(o), -ec'e (-et'e) are still found in some south-western Byelorussian dialects with verbs of the second conjugation, and the use of has been well documented. ${ }^{19}$

The second of B-K's 'uniquely Ukrainian' phonetic features is the change of etymological o to $\Gamma$ in closed syllables. Only one example is cited: розки(ш)не (P51r). It seems to the present author that this is a misreading for розли(ч)ые. The word in question has a superscript mark over the и in the form of two short curved lines. This mark is also found on P51v on a word which must be сма(ч)но. The fourth letter is more obviously л than к. It occurs next to pозмайте (cf. Polish rozmaicie, Ukrainian розмаїmo) and is translated into Latin as multijariam. In the light of this Latin word, розличне (cf. Polish rozlicznie) makes better sense. If this is the correct reading, there are no examples of this sound change in either text. Even so, it is worth mentioning that $i$ is pronounced in place of etymological stressed 0 in certain south-western Byelorussian dialects. ${ }^{20}$

The third feature is the apparent confusion in writing between the vowels $и$ and ы. The following spellings are found: н(а)шихъ (Р4r), нашы(х) (P5r); оуши, 'очи (P13r), оушы, 'очы (P16r); слодший, найслодшый (P17r); в Парыжоу (Р62v), в Парижоу (Р69r); Хрис-

17. I. I. Zen'ko, 'Važnejšyja asablivaści fanetyčnaj sistemy i hramatyčnaha ładu havorak Pružanskaha rajona Bresckaj voblaści'. Pracy. Instytuta movaznaūstva AN BSSR ,111, Minsk, 1957, p. 152; A. I. Žuraūs'ki, History ja biełaruskaj litaraturnaj movy, I, Minsk, 1967, p. 325.

18. E. Blinava and E. Miacielskaja, Biełaruskaja dyjalektałohija, Minsk, 1969 (cited hereafter as $B M$ ), p. 66.

19. Ibid., pp. 100-1.

J. F. Mackievič, Marfałohija dziejaslova ŭ biełaruskaj movie, Minsk, 1959, pp. $234-5$.

20. $B M$, p. 26 . 
тосъ (Р3v), хрыстоу (Р4r), христа (Р5r); моученици, м(оу)ч(е)н(и)цы, пророцы (P5r); диспоутациа (Р62v), лекцыю (Р88v); жывымъ, жизни (A16v); хероувими, хероувимы (P4r). It has already been noted that the sound values of $\ddot{i}$ and $и$ are differentiated in the table on A6. On the basis of the examples, и and ы could be taken as representing the same phoneme. However there are many examples where the two vowel signs are apparently being used in opposition, with interchangeable $\ddot{i}$ and и: высокї й, низкий (P8v), чарнейшї й, зацнейший (A32r), вторый, другий, третий (A84r). Similar opposition can be found in the noun declensions: староста-старосты, вольволы but камень-камени лазня-лазни. The most obvious conclusion is that $\ddot{i}$ represents the front vowel after palatal consonants, and ы the back vowel after hard ones, with и oscillating between them. The velar consonants occupy a special position in that, although they must be presumed hard (страхъ, мрокъ ведлугъ), they are followed by $\ddot{i}$ or и. Variant spellings such as очи, очы; Парижоу, Парыжоу doubtless result from the difference between inherited spelling and pronunciation. Nominative plurals such as ангели and серафими can be explained on the basis of the original case ending of $O$-stem nouns; words with religious connotations are more likely to preserve their historic form. The spellings тисяча/тисеча (A85) are well attested in Byelorussian texts. ${ }^{21}$ In certain Byelorussian documents of the seventeenth century there was a tendency towards the hypercorrect use of $и$ after etymologically hard $r^{22}$ A century earlier Skaryna had used both рибы and рыбы. It seems that Uževič was trying to regularize the use of these letters in A. by limiting b to final position ('in fine', A6v), but no clear and absolute distinction was made in usage between $\ddot{i}$ and $и$.

The final phonetic feature listed by $\mathrm{B}-\mathrm{K}$ is the change of $e$ to o before a hard consonant: чотыри, четве́ ртый; шесть, шостый (A84r). There seems to be nothing specifically Ukrainian about this, cf. Byelorussian $и э c u s$, , шостьл.

The first Ukrainian morphological feature is, according to B-K, the dative masculine singular noun ending -ови. This ending is found four times in all, in A. only: Цареви (three times on 14r), Богови (19r, where it occurs next to Богоу). It is nowhere listed in the noun paradigms as an alternative ending, whereas the $\check{u}$-stem nominative plural ending -ове is. This isolated usage of the dative singular ending -ови could be evidence of Polish influence on noun declension. ${ }^{24}$ The ending was being used more and more widely in Byelorussian texts of the period, ${ }^{25}$ and is still found in some dialects of the Brest region. ${ }^{26}$

21. Bułyka, op. cit., p. 118.

22. Ibid., p. 109.

23. N. N. Durnovo, Vvedenie v istoriju russkogo jazyka, Moscow, 1969, p. 171.

Karskij, op. cit., pp. 170-86.

24. Karskij, Trudy po belorusskomu $i$ drugim slavjanskim jazykam, Moscow, 1962, p. 471.

Bułyka, op. cit., p. 133.

25. Žuraūski, op. cit., p. 325.

26. $B M$, p. 65 . 
The second feature is the genitive singular of such nouns as теля and время - телятя, временя. This is a trait of the upper Dniestr dialects of Ukrainian, but it is equally a feature of standard Polish. There is an interesting remark, perhaps a slip of the pen, on P15r. Uževič has just given the paradigm of теля and listed other nouns, such as порося-поросята, щеня-щенята. He continues: 'Excipe nomen имя, quod genitivum format именя non имяти. On the basis of the previous examples the incorrect form should have been ${ }^{*}$ имятя. ${ }^{2 *}$ The ending -ти is exactly parallel to that of modern Byelorussian, cf. Byel. иялл, ияляци,, Polish cielę, cielęcia.

The absence of written double consonants resulting from the loss of $\mathrm{b}$ in the Common Slavonic *bje is cited by B-K as further evidence of Uževič's language being Ukrainian: кованя (A45v), from which the verbal noun коване is formed. One of the features of modern Byelorussian is the doubling of $\mathrm{t}$ and $\mathrm{d}$ (which become ć and $d z^{\prime}$ ), $l, n$ and the sibilants in this position. Karskij ${ }^{28}$ gives examples from early Byelorussian writings with doubled consonants. Throughout the sixteenth and seventeenth centuries variant spellings of the verbal noun ending were used: наказаніе, мовене, or with superscript $\mathrm{H}$ as in мешка(ы)e, ${ }^{29}$ with the possibility of Polish influence on the form -He. The doubling of certain consonants in this position is also a feature of Ukrainian, e.g. забуття, приладдя, заедания, побережэюя so no definite conclusion can be drawn from their absence in Uževič's grammar.

The fourth morphological feature is the genitive plural ending -ий, found once only in the phrase за тыхъ дний (Р62v). This form of the ending is unexpected, since день is listed on P15r as an example of a noun following the paradigm of камень (P14r). There the genitive plural form is каменевъ, sо *дневъ would have been expected. The ending -ей, either stressed or unstressed, is found in modern Byelorussian: конь-ко́ней госиъ-гасие́й. ${ }^{30}$ It is derived from the gen. plu. ending of the $i$-stem noun declension, where it had the form ьи $(>$ еи $>$ ей), The form днии is found in Skaryna and seventeenth century Byelorussian texts; ${ }^{31}$-ей is also found in documents of the period. Uževič has грошей as the gen. plu. of грошъ in both P. and A.: тес(к)но пана безгрошей (Р57r), наддати грошей (A76v); гостей in веле у тебе есть гостей (P68r). It seems possible to assume that the ending -ей had a variant form -ий, and was used with some original $o$ - and $i$-stem nouns with soft or hardened final stem consonants, although it is listed only in the declension patterns of soft feminine nouns: пъснь-пъсней, лазня-лазней (Р15v), сталь-сталей (А27v). The form людей, in оумерло килка люде' (P66r) may be deduced from the note on A38v: 'люди homines 4tae declinationis'.

27. Skaryna has: не отнимай от дитятя твоего казни (Proverbs, 23).

28. Karskij, Belorusy, I, pp. 292-301.

29. Bulyka, op cit, pp. 89-90.

30. M. I. Hurski et al., Biełaruskaja mova, I, Minsk, 1968 (cited hereafter as $H B)$, p. 215.

31. Karskij, op. cit., pp. 219-21. 
The augmentative suffix -иско is also quoted by B-K as a Ukrainianism, as it is widely used in the south-western dialects of Ukrainian. It occurs in several words on $\mathrm{P} 12 v$ and A22v, e.g. хлописко 'crassus vir'. This suffix is not listed in a recent grammar of modern Byelorussian ${ }^{32}$ but it is found in the dialect of the Zelva district, Hrodna region, and was used in old Byelorussian documents. ${ }^{33}$ It may be regarded as a Polish loan form.

One piece of syntactic evidence is adduced by B-K in support of their case: the use of the genitive of non-animate masculine nouns for the accusative, e.g. поправи(л) малярь образа (Р58v, but cf. малюючи обра(3) (Р65v)). This is certainly a peculiarity of Ukrainian, but the genitive is by no means always used in this instance. ${ }^{34}$ This use of the genitive must be distinguished from the genitive used with partitive meaning (P57r). It should be noted that the sentence given above occurs in a list of verbs, mostly prefixed, which require a direct object in the genitive case. The list in P. is much fuller than that on A76r. No general rule on the use of the genitive instead of the accusative can be derived from the examples given in this list, since they are given as exceptions to what Uževič says on P12v: 'Nomina huius declinationis in $\mathrm{b}$ terminata si fuerint rebus inanimatis imposita Accusativum utriusque numeri similem habent Nominativo'. This clarification, which is also given on A23r, is needed because the fully declined example is панъ, with identical accusative and genitive forms пана-пановъ (although паны is given as an alternative ace. plu. form). P56v Uževič says: 'Verba Activa pleraque accusativo adstipulantur ut облегль мъсто obsedit Civitatem, забиль звера стрелець, then goes on to describe the use of the partitive genitive and to give the list of verbs requiring a direct object in the genitive, some of them in certain meanings only. Among the non-prefixed verbs included in this list are оучоу, броню, стерегоу, виншоую, слоухаю, жычоу. Polish influence must be making itself felt here. The genitive is sometimes used in accusative position in the dialects of southwestern Byelorussia.

None of the features singled out by B-K as Ukrainian and not Byelorussian can be regarded as such after closer examination. They are to be found in early Byelorussian texts and many of them in modern Byelorussian dialects.

Many features of Uževič's grammar, phonetic, morphological and syntactic, are not discussed individually by B-K, but are nevertheless worthy of specific mention.

The change of quality of unstressed vowels is occasionally reflected in spelling. The change of е to и has already been mentioned. The

32. $H B$, pp. 221-2.

33. P. U. Stecko, 'Marfałahičnyja asablivaści havorak Zelvienskaha rajoma Hrodzienskaj voblaści', Pracy Instytuta Movaznaŭstva AN BSSR, VIII, Minsk, 1961, p. 164.

$H L$, p. 100 .

34. G. Y. Shevelov, The Syntax of modern literary Ukrainian, The Hague, 1963. p. 168.

35. Narysy pa biełaruskaj dyjalektałohii, Minsk, 1964, p. 310; BM, p. 65. 
change of unstressed $x$ to e is reflected in the spelling of the reflexive particle, наскакатися, начиталсе (both A47r), and in the following: десеть (Р60r, А84r), десять (Р64v), светымъ (Р68r), святый (A31v), cf. Byel. святы́l. The pronunciation of unstressed o as $a$ is not found, unless сарбона (the Sorbonne) can be taken as an example. The pronunciation of unstressed $e$ as $i$ is reflected in стрымя́ 'stapes' (A27r), cf .Byel. стрэ́мя. The reason for the different stress position is not clear. Polish nasal vowels are rendered as follows: о(т)тондъ \{ottą) (Р49r), хендокгий (chędogy) (P61v).

If the acute accent on vowels is correctly understood as a stress mark, then several inconsistencies become apparent, quite apart from the fact that by no means every word is marked, e.g. написа́ на (title page of P.), напи́санá (title page of A., cf. написа́лемъ (A81r). Both кре́мень and креме́нь are found on А26v. Ре́мень and кре́мень contrast with Byelorussian рэ́менъ, крэ́менъ. Оге́нь (A26v) is interesting in that the apparent stress position is Byelorussian (аго́нъ) or (ого́нb), whereas the actual form of the word is Polish (ogień).

The following resolutions of liquid diphthongs are found: ело(д)кї и (P8r), сребрный (Р9v), берегъ (Р12v, А22v), нагорода (Р68г), слонце (P67r, A77r). Both Polish and East Slavonic pleophonic forms of many words exist side by side: чловекъ (Р13v, А38v), человькъ (Р3v); золотый (P9v), зло́то (A40r); кроль (Р54v, A81v), кролезъская (Р54v), королев'ская (А75v).

The system of adjectival declension is more fully described in A. than in P., if only because no feminine singular forms are given at all in P., except for the nominative. P. does, however, have an alternative feminine singular nominative ending which is not given in A.: -a. This ending may be due to Polish influence; it is still found in the dialects of the Minsk, Hrodna, Brest and part of the Homiel regions. $^{36}$ The bisyllabic genitive feminine singular ending -ой, -ей still occurs in certain south-western Byelorussian dialects. ${ }^{3 \%}$ Similarly the nominative plural ending ый may be found in the dialects of the Brest and Pinsk districts.

Uževič distinguishes between the Common Slavonic comparative

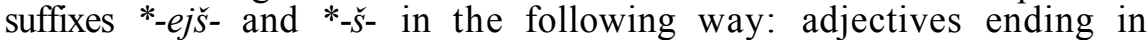
ный, рый and лый change the ы to $\mathrm{b}$ or e, euphoniae causa (P16v), e.g. зацный-зацнейший. An additional note on $\mathrm{A} 32 v$ states that adjectives ending in лый have two comparative forms: сталыйсталейший or сталший. Adjectives with the suffix -ок- lose it in the comparative degree: шерокї й-шер'ший, высокї й-вышший. Both P. and $\mathrm{A}$. have short lists of irregular comparison, but only $\mathrm{P}$. gives the alternative comparative and superlative forms венкши'-на'венкши' for великий ('Dicitur etiam praesertim Polonis', cf. Pol. większy, największy). These Polish forms reappear in the comparison of the adverb веле $(\mathrm{P} 51 v)$ - венцей, найвенцей. Comparative and superlative forms found in both versions of the grammar: ясньйшое, наймоудрейший (A77r); проудшый < проудкий (P48r), пенкнђйши',

36. Ibid., p. 83.

37. Ibid., p. 84. 
срожший (cf. срокго, сродзе (Р51v), наичистшая (P67v). Rules on P67v; and A77r explain the syntactic use of the comparative: it either governs the genitive, песъ проудшый кота, or is followed by надъ and the accusative, слонце ясньйшое надъ мъсець. Both comparative and superlative forms are possible in sentences such as левъ срожший мелей звератами (Р.) and слонце найясньшое межи планетами (А.). Similar sentences can also be formed by using the preposition 3 and the genitive, the construction used in modern Byelorussian and Polish.

The formation of adverbs from adjectives is dealt with on P48r and $\mathrm{A} 72 r$. In both cases the ending -e is described as more common than -o; only in A. is there an example of an adverb having both endings: смачне, смачно.

Uževič gives four noun declensions, declining each noun through six cases in the singular and plural. The cases are: nominative, genitive, dative, accusative, vocative and ablative. This last is the instrumental. The locative case did not fit easily into the essentially Latin scheme of noun declension, so it is described in a separate note on $\mathrm{P} 17 v$ and $\mathrm{A} 33 r$, and called 'casus vagabundus'. As a rule singular locative endings are not listed in the paradigms; the plural endings are given next to those of the 'ablative'.

The first declension, that of $a$-stem masc. and fem. nouns, is represented in both texts by староста. Only masc. nouns of this declension may take the genitive plural ending -овъ. Two dat. plu. endings are given, -амь and -омь, but no distinction is made between them. Velars are palatalized before the front vowel ending of the dat. sing. The locative singular endings e/ $\mathrm{b}$, with староста and шапка respectively, have already been mentioned. The ending ий occurs in the word Франция (Р60v).

The second declension is that of $o$-stem masc. and neut. nouns. Only one ending (-a) is listed for the gen. sing., although the following nouns, taken from both texts, have оу: анимоушъ, голосъ, довтипъ, домъ, коштъ, пляцъ, Римъ, рокъ, фрасоунокъ, часъ. The ending occurs both with and without prepositions: соуптелность довтипоу, пошоль до домоу. This ending was spreading in the sixteenth century from abstract and collective nouns to concrete ones; ${ }^{38}$ it was an element of the spoken language adopted by the literary language. The voc. sing, ending is e (also $\mathbf{b}$ in P.); in a note Uževič adds the ending oy for nouns ending in хъ, къ and шъ. Certainly in the case of $\mathrm{xъ}$ and $к ъ$, the new ending avoided the palatalization that would have been caused by e. Three nouns, Богъ, мешокъ and Парижь have a loc. sing, in oy, which can presumably be explained in the same way. Both ы and ове are given as nom. plu. endings. The latter, historically a form belonging to the $\breve{u}$-stem declension, increased in usage in the second half of the sixteenth century. ${ }^{39}$-e is used as

38. Ž uraйski, op. cit., p. 273.

39. Ibid., pp. 244, 273. It is worth noting that the ending -ове is also given for the vocative plural of nouns like староста (Р11r, A20v). 
a nom. plu. ending twice: жолньре (Р64r), христіяне (P68r). It is not surprising that a Polish loanword should have adopted a Polish grammatical ending, cf. zotnierz - zotnierze. That this borrowing is only partial is shown by the gen. plu. жолнъровъ, cf. Pol. zolnierzy. The neuter nom. plu. ending -a is still found in south-western Byelorussian dialects, alongside the stressed dat. plu. ending -омъ. ${ }^{40}$ The inst. sing, ending -емъ (instead of -омъ as listed) is found with one word: ножемъ (P59v, А77v).

The third declension contains soft-stem masculines (ending in $\mathbf{b}$ and й) and neuters in e. The ace. of both sing, and plu. has two endings - nom. and gen. (nom. only in plural in A.). The sample noun in both versions is камень, so the question of animation does not arise. The diminutive neuter plural телятка, assigned to the second declension in P., is treated as an exception to the third declension in A. Neuters of the tyре имя, теля are included here. The old i-stem inst. plu. ending is found with one word: конми (Р59v).

The fourth and final declension is that of soft fern, nouns: пъснь (Р), сталь (А.), лазня (both). Ablative' sing, ending is -ею, gen. plu. -ей, dat. plu. -емъ. The plurals of око (очы) and оухо (оушы) are declined according to this pattern, as are feminine nouns in $\mathrm{b}$, e.g. моць, оброжъ, кровъ, крыновъ.

Examples of singularia and pluralia tantum, and of noun and adjective building, are given in A. only.

As far as the syntax of nouns is concerned, the category of animation is one of the most striking features of any Slavonic language. Uževič leaves the question almost unmentioned, except for the note on $\mathrm{P} 12 v$ and $\mathrm{A} 23 r$ already referred to. It is at least clear that nouns referring to humans and animals have an ace. similar in form to the gen., at least in the sing.: я маю своего пана (P56r), забиль звъра стрелецъ (Р56v). From the sentence въмъ ижъ Богъ грьшныхъ боуде(т) карати (Р65v), and from the paradigms, it can be seen that this applies to nouns referring to humans in the plural as well. In мњлемъ сокола который качки живо ловиль (Р54r), the form сокола can be deduced from the statement on P12v; *качекъ would have been expected by the same rule, unless this rule does not apply to plural nouns which are not masculine, or it is assumed (and this is more likely) that Uževič was following the animation rule of Byelorussian and Polish. If this is so, Uževič's usage may be formulated as follows: in the singular all masculine animate nouns have an ace. which is identical to the gen., whereas in the plu. this is true only of nouns (both masc. and fem.) denoting human beings.

A number of other syntactic points connected with nouns also deserve mention. A derived adjective is usually preferable to a genitive when signifying possession: конь гетманскї й rather than конь гетмана. The 'ablative' is used after the copula verb and verbs like стаю/ставаю, кероую. The nominative plu. is used after the numerals два, три, чтыри, the gen. plu. after пять upwards.

The personal pronouns have several variant forms in declension, 40. BM, p. 74 . 
including enclitics (ми, мя from я). No genitive is given for either я or ты, although it must have been the same as the acc., as with the plural мы and вы. The third person pronouns are listed with the demonstratives.

Several interesting features are found in the section on possessive pronouns: нашъ/нашый, вашъ/вашый, наша/нашая, ваше/вашое. Two forms of the gen. sing, of the reflexive свой are given in P.: своего, свого. These forms can be compared to Polish mojego, mego, literary Byelorussian майго, and the dialect forms of the western Hrodna region, a large part of the Brest region, and the south-western part of the Homiel region, маго́, сваго́. ${ }^{41}$ There is apparent inconsistency (in P. only) in the accent marking of the fem. gen. sing.: мoen, твоей, нашей, but своей. If the sole example of й is not a simple slip of the pen, it might be a reflection of the two endings known in modern Byelorussian: нагаай, нашае. The demonstrative pronouns have both long and short forms: той, тая/та (тоя in A.), тое/то. The third person pronoun is онъ/оный. The contracted form of the gen. (го $<$ оного, ихъ $<$ оныхъ) can be used as the direct object of a verb (взяльго, забильго); the singular contracted form cannot be used after prepositions (except as него), whereas the plural form can (also as нихъ). This information is not given in A. Two forms of the interrogative pronouns are given: который/котрый, кто/хто, што/що, the former obviously corresponding to modern Byelorussian, the latter to Ukrainian. Uževič makes no distinction between them, and so it seems safe to assume that he regarded them both as literary and therefore acceptable. The pronoun што/що has a variant form цо $(\mathrm{P} 51 v, \mathrm{~A} 37 v)$. The suffixes -колвекъ and -съ are evidently Polish borrowings.

The verb occupies most space in both versions of the grammar, but the presentation is different. The verhum substantivum is given first in P., with only one other verb fully conjugated - пановати. Тwo conjugations (with ковати and варити as examples) are given in A., together with a fully conjugated Old Church Slavonic verb (глаголати). Another important difference is the presence of dual forms in $\mathrm{P}$. and their total absence (except in the OCS verb) in A.

The third person ending, sing, and plu., is -ть, that of the first person plu. -MO (Р.), -мъ (A.). The past tense has personal suffixes like Polish, е.g. пановалемъ (or -лехъ), пановалесь, etc. The three genders are distinguished in the singular but not in the plural except that the fem. form may change и to observatur' (P26r). The infinitive may end in either -ти or -ть. The third person imperative is made up by the particle нехай and the corresponding indicative form. The first person plu. imperative has various endings: коуймы, варьмо, поклонї мъся. The first person sing, of the subjunctive is compounded with быхъ in Р. and бымъ in A., and the simple past form in -лъ. No distinction is drawn between the compound future and the simple, usually prefixed, future ('haec futurorum cum praepositionibus compositio usu magis quam arte

41. Ibid., pp. 83-4. 
innotescit' (P28r)). There is a 'participium absolutum' ending in -чи, and a true participle derived from it, ending in -чий. The indeclinable past gerund is not dealt with in the section on the verb of either P. or A.; it occurs under the heading 'De ablativo absolute' in both versions. It ends in -вши, and is formed either from the infinitive (P.) or from the past tense (А.). The 'gerundium' ends in -аня, e.g. кованя, вареня. The verbal noun is derived from this form by changing the $я$ to $\mathrm{e}$, and the past passive participle by changing the $я$ to $\mathrm{b}, \mathrm{a}, \mathrm{o}, \mathrm{e.g}$. писаня-писане, писанъ, etc.

The grammatical function of this 'gerundium' is mysterious, since it is not dealt with at all in the sections on syntax. Its only purpose seems to be to provide the base form for the verbal noun and the past passive participle. It is similar in form to the modern Ukrainian verbal noun, e.g. кохання, ходіння, but Uževič is careful to distinguish it from the verbal noun in his grammar. The conclusion seems unavoidable that he has in fact invented a verbal form on the model of the Latin supine. He is therefore able to give the principle parts of verbs in the Latin fashion: спеваю, спеваешъ, спевалемъ, спевати, спеваня (P31r). Verbs are classified according to the ending of the first person sing. One of the few clear differentiations of aspect occurs on P31v with the past tense of оумираю: it is оумарлемъ if a 'verbum perfectum' is needed, оумиралемъ if 'inchoativum'. Similarly on A58v, позволяю has two forms of the past tense, позволилемъ and позволялемъ, 'hoc tamen secundus magis praeteritum imperfectum vel plusquamperfectum videtur'.

Verbal forms of special interest are:

i) the past tense of ити: ишолемъ or шедлемъ (A64r), with plu. шлисмы (Р63r).

ii) хочоу $(\mathrm{P} 42 v)$ has some interesting imperative forms:

1.

2. хоти

3. неха' хоче(т)

хотьмо

хтђте/хотьте

нехай хочоуть/хотять

iii) the athematic verbs:

(a) въмъ (this form only, $\mathrm{P} 65 v^{\prime}-$ otherwise знаю)

(b) дамъ $(\mathrm{P} 31 v)$ даси/дашъ дасть/да

(c) Ђмъ (A57r)

еси

bсть дамо даете дадоуть ьмы ьсте едять

imperative: ежъ, ьжмы, ьжте infinitive: ьсти, ьсть

(d) (и)мамь has been recast as маю, with infinitive мьти.

(e) есмъ has given way to the Polish:

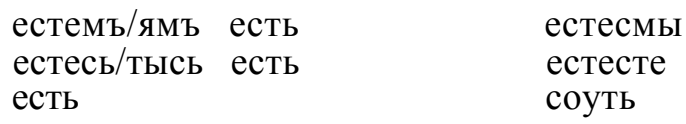


All the verbal endings used by Uževič are well attested in Byelorussian texts of the sixteenth and seventeenth centuries. The third person sing, ending -ть, for example, is found with verbs of both conjugations in the works of Skaryna and Ciapinski, and reflects the colloquial pronunciation of the time.

An interesting item in the section on the syntax of the verbs is the use of neuter passive past participles with a direct object, e.g. стято мече(м) святоую Екатериноу, написано листь (both P66r).

Both versions of the grammar have full lists of adverbs, conjunctions and prepositions. Only P. has a series of adverbs with diminutive suffixes, смачно-сма(ч)нюхно-смачнюсенечно and examples of the comparison of adverbs. On the other hand P. has no complete list of either cardinal or ordinal numerals. This is given right at the end of A., with два, три, чтыри declined on $82 v$.

Of special interest among the prepositions is the fact that в is listed as taking only the 'casus vagabundus'. It can, however, govern the ace. in a time phrase, e.g. в той часъ. По also takes the 'casus vagabundus' in the meaning of 'after'. 3a governs the genitive in time phrases denoting duration, e.g. за погоды пожаль жито (Р62r). Latin ad is translated bу до and the genitive.

One of the most obvious features of Uževič's language is its great indebtedness to Polish. Polish influence can be felt in morphology, especially in the past tense endings of verbs, and in syntax, but most of all in vocabulary. Words of all kinds have been borrowed from Polish: nouns - вязень, мрокъ, кроль, щоудлокъ;

the nominal suffix -ца, as in вымовца; verbal nouns without epenthetic л:збавене.

pronouns - ктоколвекъ, цось.

adjectives - зацный, пенкный, пожитечный, чарный.

verbs - милчоу, сковычоу.

adverbs - быле, внеть, гоурмомъ, допюро, досыть, зали, зприпадъкоу, кгды, назаютръ, теразъ, тылко.

conjunctions - вжды, звлаща, поневажъ.

prepositions - подлоугъ, презь. ${ }^{43}$

The language used by Uževič in the two versions of his grammar is surely the literary language of the Grand Duchy of Lithuania, which may be considered part of the linguistic heritage of Byelorussia. If it is assumed that the Uzewicz of Cracow University and the author of this grammar are the same person, and that he was born within the diocese of Vilna, then there are grounds for the further assumption that he came from somewhere in south-western Byelorussia, perhaps the area of Pružany. A final answer must await the result of further research.

The author would like to express his thanks to Fr. A. Nadson, Librarian of the Francis Skaryna Byelorussian Library, London, and to. Dr. J. G. Landels of the Department of Classics of Reading University, for their help in the preparation of this article.

42. A. U. Arasonkava, 'Asnounyja tendency! u razvicci asabovych form dziejaslovau u biełaruskaj movie (pa materyjalach biełaruskaj pismiennasci XVI st.)', Pracy Instytuta Movaznaustva AN BSSR, V, Minsk, 1958, pp. 86-115.

43. Many of the words contained in the word-list to both versions of the grammar in the Kiev edition (pp. 74-112) are also listed in the chapter on Polish borrowings in $H L$, pp. 89-104. 